\title{
Adsorption Dynamics of Agricultural Waste Activated Carbon in Water Quality Improvement
}

\author{
Igbemi Arthur Igbemi, Ify L. Nwaogazie, Onyewuchi Akaranta, and G. O. Abu
}

\begin{abstract}
This study investigated the removal of Lead and Cadmium ions from aqueous solution using activated carbons from agricultural wastes. Activated carbons prepared by chemical activation using Phosphoric acid were characterized by Fourier Transform Infrared (FTIR), Scanning Electron Microscopy (SEM) and Brunauer-Emmett-Teller (BET) analysis. The influence of contact time, initial concentration and adsorbent dose which governed the efficiency of the process was ascertained through batch adsorption studies. Adsorption isotherms were determined by correlating with Langmuir and Freundlich isotherms and the kinetic studies were correlated with pseudo first order and pseudo second order equations. The results showed that the amount of Lead and Cadmium adsorbed decreased as the adsorbent dose increased while the adsorption capacity increased with increased in contact time and initial concentration. Activated carbons prepared from Coconut shell and palm kernel (shell and cake) competed favorably with the commercial activated carbon in percentage removal of the metal ions as all the activated carbons had over $90 \%$ removal within 60 minutes when $1 \mathrm{~g}$ of adsorbent was used. The equilibrium data fitted best into Freundlich isotherms for both metal ions. The rate of adsorption could be described by pseudo second order for all the adsorbents except Coconut shell activated carbon in the adsorption of Lead while intra-particle diffusion was the limiting step for Cadmium adsorption. Therefore, the agricultural by-products can be used as effective, low-cost, and environmentally friendly adsorbents for domestic water treatment in many parts of the world.
\end{abstract}

Key words - Activated carbon, Adsorption, Agricultural waste, Cadmium, Isotherm, Kinetics, Lead.

\section{INTRODUCTION}

Heavy metal pollution of water has become a threat to the environment and public health due to its toxicity, accumulation in food chain and presence in nature [1]. The conventional methods for heavy metal removal from water and wastewater include oxidation, reduction, precipitation, membrane filtration, ion exchange and adsorption [2]. Adsorption method has been found to be less expensive and useful in environmental application such as wastewater treatment, where it is used for purification, decolourization and the removal of toxic organics and heavy metal ions

Activated carbon is one of the most effective, versatile, and useful adsorbents for the removal of pollutants from polluted gas and liquid streams because of its large adsorption capacities, extremely high surface areas, well developed pore

Submitted on October 01, 2021.

Published on October **, 2021.

Igbemi Arthur Igbemi, Centre for Occupational Health, Safety and Environment, University of Port Harcourt, Nigeria.

Ify L. Nwaogazie, Department of Civil Engineering, University of Port Harcourt, Nigeria.

(corresponding e-mail: ifynwaogazie@ ${ }^{@}$ yahoo.com) structures, fast adsorption kinetics and good mechanical properties [3], [4]. Commercial activated carbon is a wellknown adsorbent for the removal of heavy metals from water and wastewater, but the high cost of commercial activated carbon has limited its use as adsorbents in developing countries. Over the years, there has been a growing need to produce activated carbon from low cost, easily available and eco-friendly agricultural waste for the adsorption of heavy metals from water sources. The conversion of agricultural wastes to value added product such as activated carbon will be an excellent method to solve environmental problem as well as generate income for local communities.

Activated carbon can be manufactured from virtually all carbonaceous materials. However agricultural wastes offer the most available and cheapest of all the known raw materials [5]. They can be prepared from a large number of raw materials; especially agro-industrial by-products like palm kernel shells, Bamboo sticks, fruit seed shells, coconut shell. A lot of research has been done on activated carbon to improve the applicability of activated carbon as a cheap, effective, and eco-friendly adsorbent.

This study, therefore, compares the adsorption capacities of commercial activated carbon with activated carbons produced from low cost and commonly available agricultural bio- waste for the treatment of domestic water, contaminated with heavy metals in Eastern Obolo, Niger Delta, Nigeria.

\section{EXPERIMENTAL}

\section{A. Raw Material Preparation}

Three activated carbons were prepared from coconut shell (CSAC), palm kernel shell (PKSAC) and palm kernel cake (PKCAC). The agricultural wastes were sourced locally from oil palm processing mills and markets in Eastern Obolo. The raw materials were reduced to small sizes with locally fabricated palm kernel cracking machine. The samples were washed with hot water and sun dried for four days. The palm kernel cake was then soaked in acetone for 12 hours and then dried in an oven at $150{ }^{\circ} \mathrm{C}$ for 4 hours.

The coconut shell and palm kernel shell were carbonized in a Carbolite muffle furnace at $700{ }^{\circ} \mathrm{C}$ for 1 hour, while the palm kernel cake was carbonized at $500{ }^{\circ} \mathrm{C}$ also for 1 hour. The carbonized coconut and palm kernel wastes were soaked in $30 \% \mathrm{H}_{3} \mathrm{PO}_{4}$ for 48 hours before further carbonization of coconut and palm kernel shell at $800{ }^{\circ} \mathrm{C}$, and palm kernel cake

Onyewuchi Akaranta, Department of Pure and Industrial Chemistry, University of Port Harcourt, Nigeria.

G. O. Abu, Department of Microbiology, University of Port Harcourt, Nigeria. 
at $600{ }^{\circ} \mathrm{C}$ for 30 minutes. The activated samples were then cooled at room temperature, washed severally with distilled water to $\mathrm{pH}$ of $5-7$, and dried in the oven at $110^{\circ} \mathrm{C}$ for 4 hours. The carbonized waste materials were then grinded into powder with heavy duty blinder. The final samples were sieved to particles size 60 mesh $(0.250 \mathrm{~mm}) \cong 250$ micron and kept in an airtight polyethylene bags for use in the adsorption experiment. A commercially prepared activated charcoal powder (CAC) from $\mathrm{CDH}$, New Delhi, India was used for comparison.

\section{B. Stock Solution Preparation}

A stock solution of Cadmium (II) concentration $1000 \mathrm{mg} / \mathrm{l}$ was prepared by dissolving $363.39 \mathrm{mg}$ of $\mathrm{Cd}\left(\mathrm{NO}_{3}\right)_{2} .4 \mathrm{H}_{2} \mathrm{O}$ in $1000 \mathrm{ml}$ distilled water. While Lead (II) concentration was prepared by dissolving $624.98 \mathrm{mg}$ of $\mathrm{Pb}\left(\mathrm{NO}_{3}\right)_{2}$ in $1000 \mathrm{mls}$ distilled water. The desired concentrations for the experiment were prepared by further dilution of the stock with distilled water. All Chemicals used were of analytical grades.

\section{Batch Adaptation Equilibrium and Kinetic Studies}

Batch adsorption experiment was used to investigate the adsorption of Lead $(\mathrm{Pb})$ and Cadmium $(\mathrm{Cd})$ from aqueous solution. Wastewater samples were simulated in the laboratory by dissolving $\mathrm{Pb}\left(\mathrm{NO}_{3}\right)_{2}$ and $\mathrm{Cd}\left(\mathrm{NO}_{3}\right)_{2} .4 \mathrm{H}_{2} \mathrm{O}$ salts in $1000 \mathrm{ml}$ of distilled water to form the stock solution of Lead and Cadmium $(1 \mathrm{mg} / \mathrm{ml})$, respectively, which were then diluted to obtain the desired initial concentration for the adsorption experiments. The optimum conditions for the adsorption of $\mathrm{Pb}$ and $\mathrm{Cd}$ were investigated at room temperature $\left(28 \pm 1^{\circ} \mathrm{C}\right)$. In each adsorption experiment, $50 \mathrm{~mL}$ of metal ion solution with a known concentration was added to $1 \mathrm{~g}$ of adsorbent in a $250 \mathrm{~mL}$ glass-stoppered flask, and the mixture was stirred on a mechanical shaker for 150 minutes at $150 \mathrm{rpm}$. The samples were withdrawn during stirring at preset time intervals, and the solutions were filtered with Whatman filter paper, and the filtrates were then separately analyzed for residual concentrations of metal ions by Atomic Absorption Spectrometer (AAS). For each batch run, the amount of metal ions adsorbed per unit mass of activated carbon at equilibrium qe $(\mathrm{mg} / \mathrm{g})$, at time $\mathrm{t}, \mathrm{qt}(\mathrm{mg} / \mathrm{g})$ and the percentage $(\%)$ removal of metal ions was determined using Equations (1, 2 and 3), respectively:

$$
\begin{aligned}
& q_{e}=\frac{\left(C_{o}-C_{e}\right) \times V}{M} \\
& q_{t t}=\frac{\left(C_{o}-C_{t}\right) \times V}{M} \\
& \% \text { removal of crude oil }=\frac{\left(C_{o}-C_{e}\right) \times 100}{C_{o}}
\end{aligned}
$$

where

$$
\begin{aligned}
& C_{o}=\text { Initial concentration of solution }(\mathrm{mg} / \mathrm{L}) ; \\
& C_{e}=\text { Equilibrium concentration }(\mathrm{mg} / \mathrm{L}) ; \\
& C_{t}=\text { concentration of solution at time, } \mathrm{t}(\mathrm{mg} / \mathrm{L}) ; \\
& V=\text { Volume of the solution }(\mathrm{L}) ; \\
& M=\text { Mass of adsorbent used }(\mathrm{g}) .
\end{aligned}
$$

The initial concentration of the simulated wastewater was varied along with the contact time and the adsorbent mass. The equilibrium data obtained were used for the kinetic studies and also fitted into Langmuir and Freundlich isotherm models.

The isotherm equations were explained using the goodness of fit, R2 and other error functions. According to the $\left(\mathrm{R}^{2}\right)$ value, the higher the $R^{2}$ value (closer to unity) the better the model for depicting the isotherm parameters [6].

Similarly, the kinetic data were also fitted into pseudo-first order, pseudo-second order and intra-particle. In all adsorption studies, R2 was used to test goodness of fit.

\section{RESULTS AND DISCUSSION}

\section{A. Characterization of Adsorbent}

Physico-chemical characteristics and potential uses of adsorbents are greatly influenced by the biomass feedstock, precursor pretreatments, carbonization method and activating condition [7]. The morphological structure of the activated carbons was analyzed with the aid of Scanning Electron Microscopy (SEM) and the images of the different activated carbons used for the experiment are presented in Fig. $1 \mathrm{a}, \mathrm{b}$, $\mathrm{c}$, and $\mathrm{d}$. The surface structure developed pores and some cavitation in the process of carbonization and activation. SEM images of the activated Carbons revealed rough, porous surfaces with cavitation. The surfaces of the commercial activated Carbon showed more cavitation and cracks than others. CSAC had some of the pores partially blocked. Prominent bright silver patches were seen on the surface of PKCAC suggesting the presence of iron oxide which is in line with the study reported by [8]. The high porosity of PKCAC is known to increase adsorption capacity [5]. The image of activated Carbon prepared from Palm Kernel Shell (PKSAC), showed smooth surface with scanty tiny pores.

The elemental composition of the activated carbons determined by Energy Dispersive X-ray (EDX) is shown in Table I and revealed significant percentage of eight elements: Carbon (C), Oxygen (O), Phosphorous (P), Aluminum (Al). Sodium (Na), Potassium (K), Silicon ( $\mathrm{Si}$ ) and Iron (Fe). The activated carbons were composed of carbon and oxygen predominantly. Energy Dispersive X-ray analysis for elemental composition of the carbons as shown in Table 1 revealed CSAC with carbon content of $69.32 \%$, as the highest followed by PKCAC 56.24\% and PKSAC 56.21\%. The least in carbon content is CAC with $18.39 \%$. The high carbon content of activated carbons prepared from Coconut shell and Palm kernel shell and cake in this study was similar to the findings in the study by [7]. This indicates that PKSAC, PKCAC, and CSAC fit into active carbons [7]. Therefore, the prepared activated carbons in this study are preferred to the commercial carbon as a result of the higher carbon content. [7], stated that Oxygen content from the elemental analysis is also an important aspect, because it can form oxygen functional groups which aid adsorption process. Oxygen content of the activated carbons in Table I is as follows: CSAC $15.01 \%$, PKSAC $35.51 \%$, PKCAC $21.91 \%$ and CAC $18.39 \%$. The high oxygen content of the adsorbents may have contributed significantly to the high percentage removal of toxic metal ions noticed in the study. 


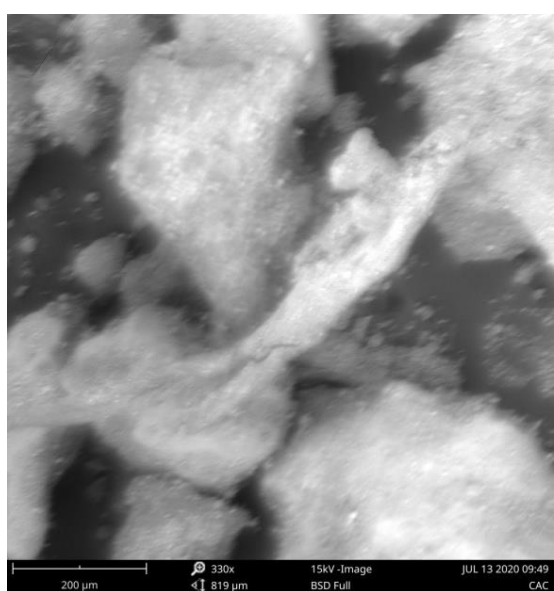

(a)

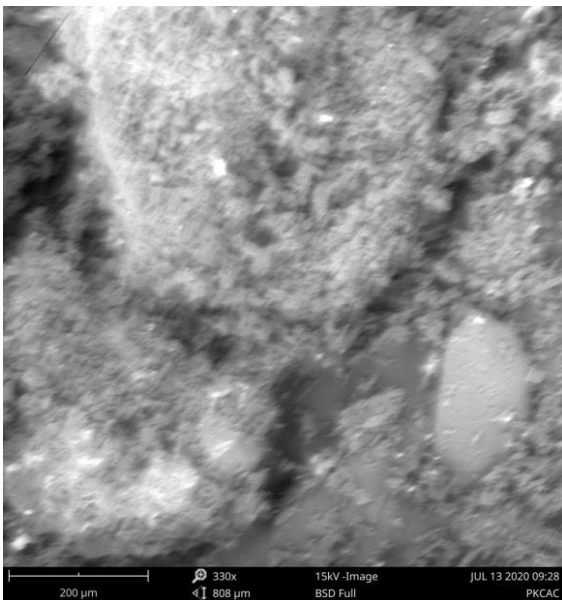

(c)

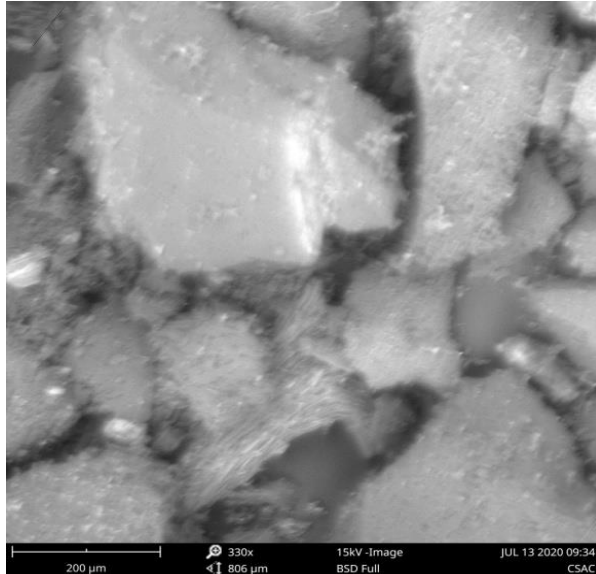

(b)

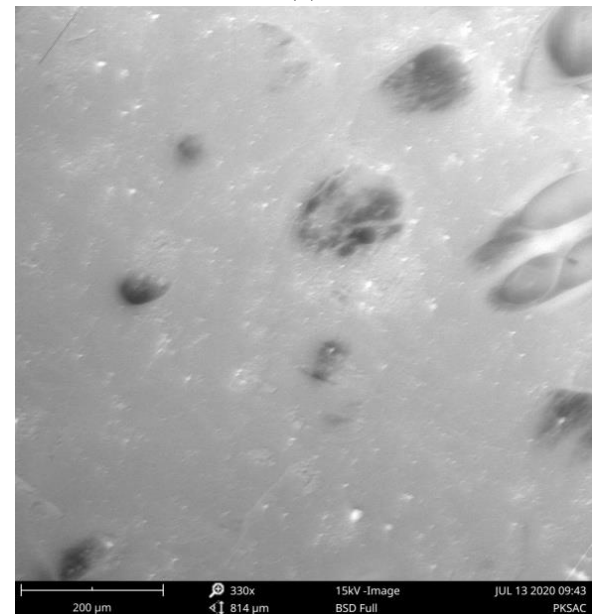

(d)

Fig. 1. Scanning Electron microscopy (SEM) images of (a) Commercial Activated Carbon (CAC), (b) Coconut Shell Activated Carbon (CSAC), (c) Palm Kernel Cake Activated Carbon (PKCAC) and (d) Palm Kernel Shell Activated Carbon (PKSAC).

Brunauer-Emmet-Teller (BET) analysis was carried out to determine the surface areas, pore volumes and pore sizes of the different activated Carbons. The result shown in Table II, gave the surface areas as follows: CSAC $826.488 \mathrm{~m}^{2} / \mathrm{g}$, CAC $626.988 \mathrm{~m}^{2} / \mathrm{g}$, PKSAC $602.074 \mathrm{~m}^{2} / \mathrm{g}$ and PKCAC $557.912 \mathrm{~m}^{2} / \mathrm{g}$. Pore size and pore volume are also shown in Table II. The BET surface area of the activated carbons shown in Table II is in the order: CSAC > CAC > PKSAC > PKCAC with good surface areas for adsorption. Large surface areas show possibility of high adsorption of organic compounds [5]. All the activated carbons demonstrated mesopore size except CSAC which showed a micropore size of less than $2 \mathrm{~nm}$ according to IUPAC classification. The high surface areas observed in the study was also reported in a study by [7], which he attributed to highly developed pore network within the carbon as a result of the ability of the activating agent (Phosphoric acid) to penetrate deep into the structure of the carbon causing tiny pores to develop.

Spectra of Fourier Transform Infrared (FTIR) for the different activated Carbons shown in Fig. 2 a, b, c and d established the presence of different peaks corresponding to different functional groups along the wavelength 4000$640 \mathrm{~cm}^{-1}$. All the activated carbons except CSAC showed strong peaks between $3000-3700 \mathrm{~cm}^{-1}$ which suggest the presence of $\mathrm{O}-\mathrm{H}$ stretching vibrations of water moieties [5], [8]. PKCAC and CSAC have peaks between 2600-2900 $\mathrm{cm}^{-1}$ which correspond to $\mathrm{C}-\mathrm{H}$ stretching vibrations from methyl group [9], [7]. PKSAC and CAC did not demonstrate the presence of this functional group. The $\mathrm{C}=\mathrm{O}$ stretching of
Carboxylic acid seen between $2000-2500 \mathrm{~cm}^{-1}$ [5] were found in all the carbons, also found in all the activated carbons were the $\mathrm{C}-\mathrm{O}$ and $\mathrm{C}=\mathrm{O}$ stretching corresponding to alcohol and carbonyl group between $1000-1600 \mathrm{~cm}^{-1}$ [5]. These different functional groups, particularly oxygen containing functional groups had been known to enhance adsorption capacity of activated carbon through heavy metal binding on activated carbon surfaces [7], [10].

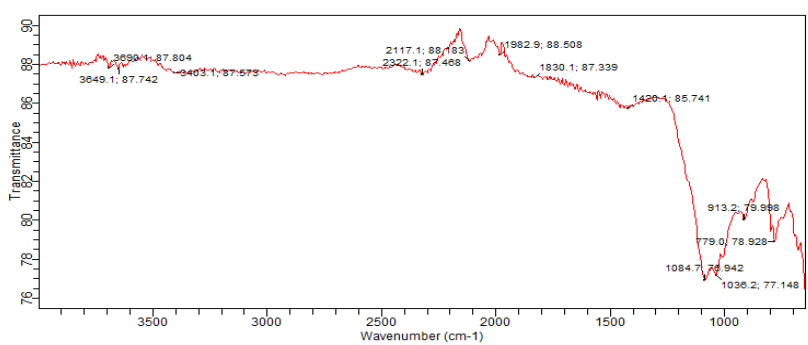

Fig. 2. (a). Spectrum of Commercial Activated Carbon (CAC).

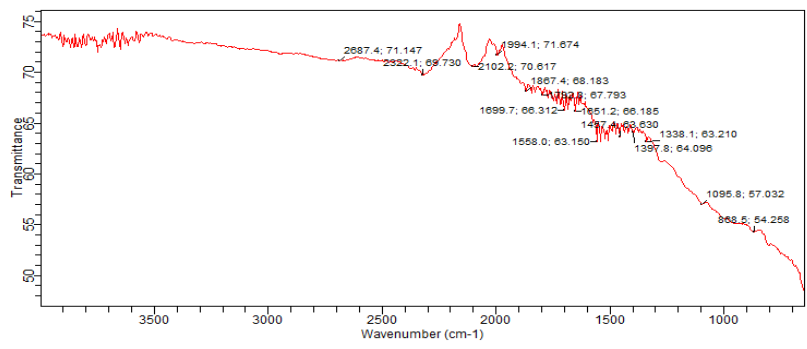

Fig. 2. (b). Spectrum of Coconut Shell Activated Carbon (CSAC). 


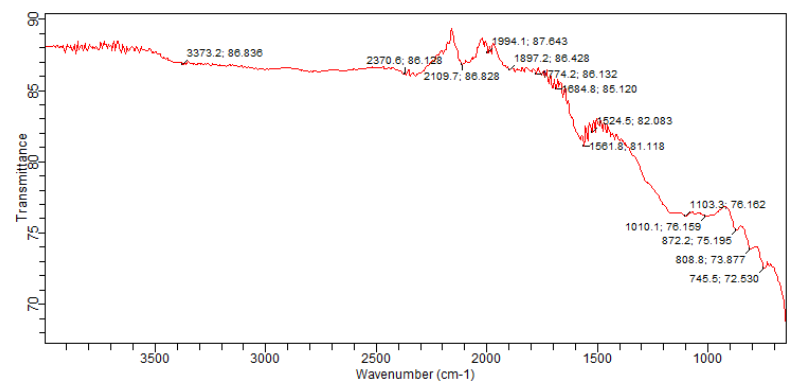

Fig. 2 (c). Spectrum of Palm Kernel Cake Activated Carbon (PKCAC).

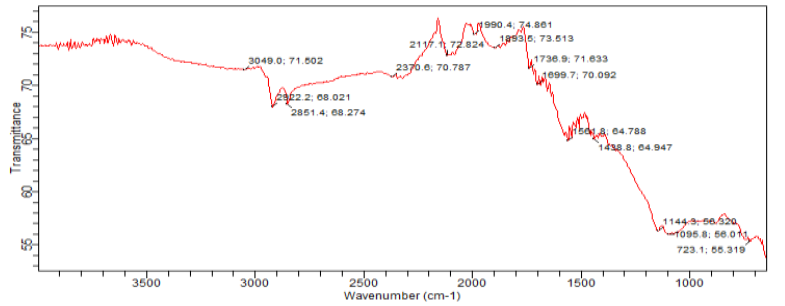

Fig. 2 (d). Spectrum of Palm Kernel Shell Activated Carbon (PKSAC).

TABLE I: CHEMICAL COMPOSITION OF THE ACTIVATED CARBONS USING

\begin{tabular}{ccccccccc}
\multicolumn{8}{c}{ EDX ANALYSIS } \\
\hline $\begin{array}{c}\text { Sample } \\
\text { ID }\end{array}$ & $\mathrm{C}(\%)$ & $\mathrm{O}$ & $\mathrm{P}$ & $\mathrm{Al}$ & $\mathrm{Na}$ & $\mathrm{K}$ & $\mathrm{Si}$ & $\mathrm{Fe}$ \\
$(\%)$ & $(\%)$ & $(\%)$ & $(\%)$ & $(\%)$ & $(\%)$ & $(\%)$ \\
\hline CSAC & 69.32 & 15.01 & 7.85 & 2.09 & 2.29 & 0.67 & 0.67 & 0.00 \\
PKSAC & 56.21 & 35.51 & 1.62 & 1.50 & 0.87 & 0.00 & 1.39 & 0.00 \\
PKCAC & 56.24 & 21.91 & 10.44 & 1.79 & 1.00 & 1.01 & 1.44 & $\mathrm{I} .08$ \\
CAC & 18.39 & 32.94 & 0.89 & 6.58 & 9.80 & 0.47 & 15.15 & 2.67 \\
\hline
\end{tabular}

TABLE II: The Surface ArEa AND Pore Structure CharaCterization

\begin{tabular}{ccccc}
\multicolumn{5}{c}{ OF THE PREPARED ACTIVATED CARBONS } \\
\hline Sample ID & $\begin{array}{c}\text { Langmuir } \\
\left(\mathrm{m}^{2} / \mathrm{g}\right)\end{array}$ & $\begin{array}{c}\text { Multi-Point } \\
\text { BET }\left(\mathrm{m}^{2} / \mathrm{g}\right)\end{array}$ & $\begin{array}{c}\text { Pore } \\
\text { Volume } \\
(\mathrm{cc} / \mathrm{g})\end{array}$ & $\begin{array}{c}\text { Pore } \\
\text { Size } \\
(\mathrm{nm})\end{array}$ \\
\hline CSAC & 0.000 & 826.488 & 0.724 & 1.520 \\
PKSAC & 3259.799 & 602.074 & 0.549 & 2.920 \\
PKCAC & 2361.649 & 557.912 & 0.506 & 2.880 \\
CAC & 3229.914 & 626.958 & 0.571 & 2.920 \\
\hline
\end{tabular}

\section{B. Effect of Contact Time}

The effect of contact time on the adsorption of metal ions was investigated and the result are as shown in Fig. 3 a and 3 b. Increase in contact time resulted in increase in percentage removal of Lead from solution until equilibrium was reached. All the absorbents had over $93 \%$ removal of Lead within contact time of $15 \mathrm{mins}$ to $150 \mathrm{~min}$. Equilibrium time was attained as follows: CSAC at $135 \mathrm{~min}$., PKSAC at $105 \mathrm{~min}$, $\mathrm{PKCAC}$ at $120 \mathrm{~min}$ and $\mathrm{CAC}$ at $105 \mathrm{~min}$. An initial rapid percentage removal of Lead was observed with CSAC. All the adsorbents used removed $99 \%$ of Lead from solution except CAC that removed $96.7 \%$ of lead within 60 minutes.

Similarly, percentage removal of Cadmium $(\mathrm{Cd})$ increased steadily with the contact time for all the adsorbents until equilibrium was reached. From the results in Fig. 3 a and b, removal of $\mathrm{Pb}$ and $\mathrm{Cd}$ from the solution increased with contact time until the attainment of equilibrium which is in line with study by [1]. The finding was attributed to increase in Kinetic energy of the metal ions and decrease in boundary layer resistance due to mass transfer in the bulk solution. This observation was also corroborated by [10]. The increase in surface area of the adsorbent and the availability of active sites are believed to be responsible for the rapid adsorption of metal ions at the beginning stage of the reaction [8].

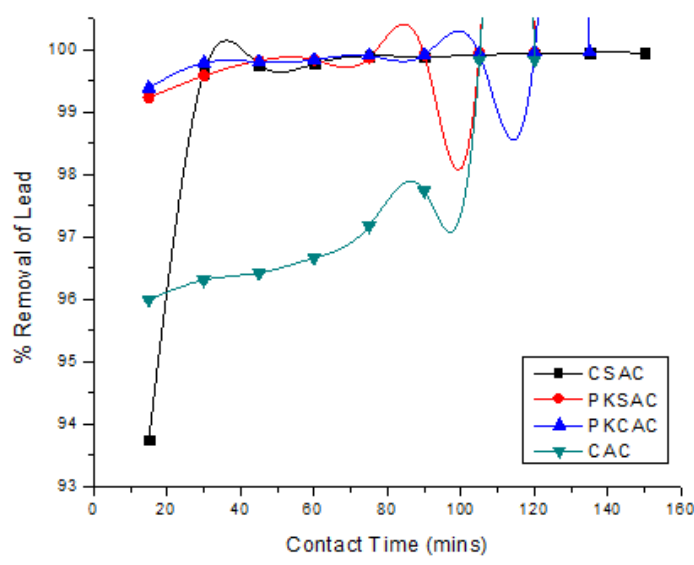

(a)

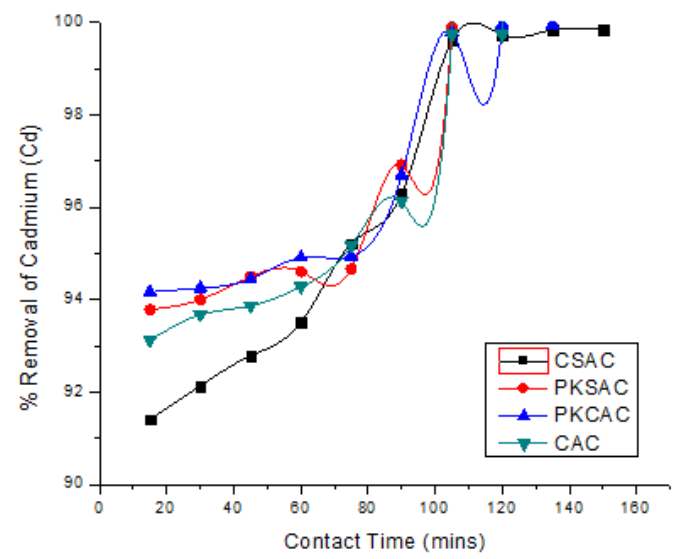

(b)

Fig. 3. The effect of contact time on the \% removal of (a) Lead (Pb) and (b) Cadmium (Cd).

\section{Effect of Adsorbent Dose on Percentage Removal of $\mathrm{Pb}$ and $C d$}

The effect of increase in doses of the different adsorbents from 1.0-3.0 $\mathrm{g}$ only resulted in marginal increase in percentage removal of both $\mathrm{Pb}$ and $\mathrm{Cd}$ with activated carbon produced from Coconut shell (CSAC) removing more than $99.8 \%$ as shown in Fig. $4 \mathrm{a}$ and 4 b. The results in Fig. $4 \mathrm{a}$ and b showing initial increase in percentage removable of both $\mathrm{Cd}$ and $\mathrm{Pb}$ with increase in adsorbent dose was in agreement with the study by [10] and was attributed to the increase in the number of adsorption site as the mass of absorbent increases. [1], however noticed a decrease in the amount of metal ions adsorbed per unit mass of the adsorbent as the mass of adsorbent doses increased. They attributed the phenomenon to adsorption sites remaining unsaturated during adsorption.

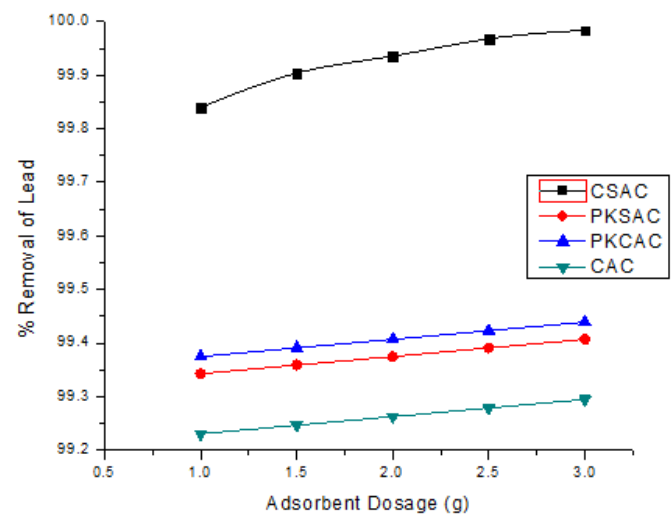

(a) 


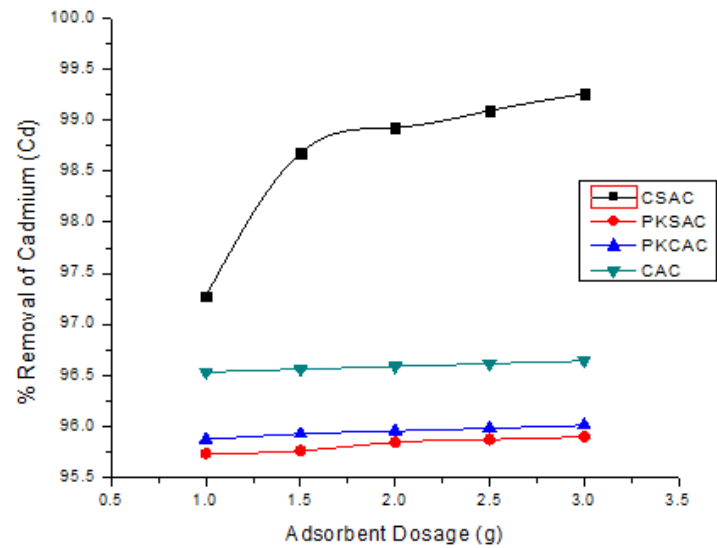

(b)

Fig. 4. The effect of adsorbent dosage on the \% removal of (a) Lead (Pb) and (b) Cadium $(\mathrm{Cd})$

\section{Effect of initial Adsorbate Concentration}

The adsorption experiment was conducted to test the effect of initial concentration of the different adsorbates on the percentage removal of metal ions. There was an initial increase in percentage removal of $\mathrm{Pb}$ with increase in initial concentration of adsorbate to a climax before a steady decline in percentage removal except for PKCAC which showed no difference. The maximum efficiency of Lead removal for each of the adsorbents was reached at initial concentration of 6.25 $\mathrm{mg} / \mathrm{l}$ for PKSAC and PKCAC, and $9.37 \mathrm{mg} / \mathrm{l}$ for CSAC and CAC. Cadmium $(\mathrm{Cd})$ showed a steady increase in percentage removal with increase in initial adsorbate concentration except for $\mathrm{Cd}$ removal on coconut shell activated carbon (CSAC) which showed a similar pattern as observed with Lead $(\mathrm{Pb})$ adsorption in Fig. 5 a and 5 b. CSAC performed better with $\mathrm{Cd}$ removal than the others. The removal of $\mathrm{Cd}$ from solution by adsorption unto the different adsorbents presented in Fig. 5 b showed an initial rapid increase in adsorption efficiency with increase in initial concentration of adsorbate in line with the report of [10] who studied the removal of heavy metals from solution using activated carbon prepared from seed shell and postulated that at lower concentration, the number of metal ions is low when compared to the available adsorbent active sites, therefore adsorption is more apparent. Thus, when equilibrium between the absorbed and the remaining ion in solution is established the rate of adsorption decreases. [1] also observed an increase in percentage removal with increase in ion concentration.

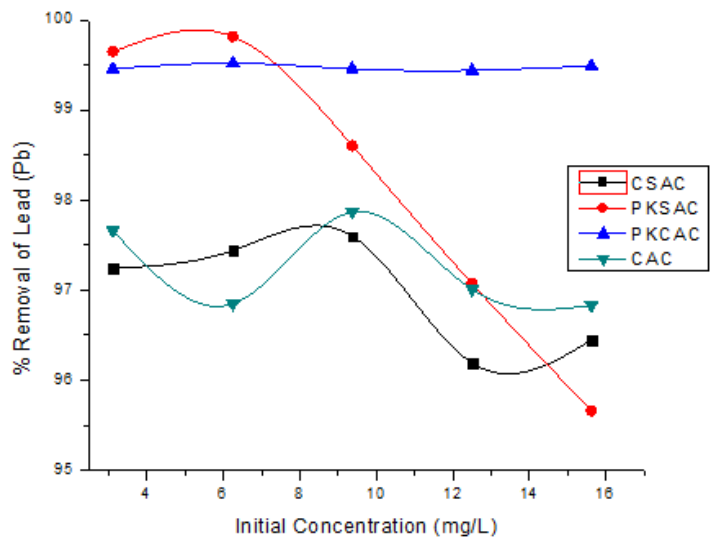

(a)

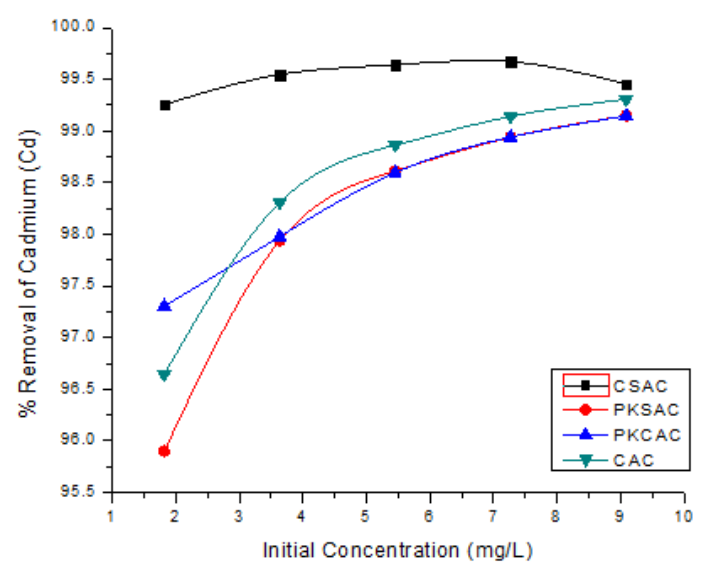

(b)

Fig. 5. The effect of adsorbate dosage on the \% removal of (a) Lead $(\mathrm{Pb})$ and (b) Cadmium (Cd).

\section{E. Kinetic Studies}

Several kinetic models have been applied to examine the controlling mechanism of metal adsorption from aqueous solution. This study applied pseudo-first-order, pseudosecond-order and intra-particle diffusion mechanism.

The different kinetic models for the adsorption of $\mathrm{Pb}$ and $\mathrm{Cd}$ onto the different adsorbents used in this experiment is compared using the goodness of fit $\left(\mathrm{R}^{2}\right)$ values as shown in Tables III A and III B. The adsorption of $\mathrm{Pb}$ unto CSAC followed Pseudo-first-order reaction with $\mathrm{R}^{2}=0.999$ while the adsorption kinetic of $\mathrm{Pb}$ unto PKSAC and PKCAC followed pseudo-second-order kinetic with $\mathrm{R}^{2}$ values of 0.987 and 0.972, respectively. Adsorption of $\mathrm{Pb}$ onto $\mathrm{CAC}$ followed an intra-particle diffusion kinetic with $\mathrm{R}^{2}$ value of 0.816 . The adsorption of $\mathrm{Cd}$ onto the different adsorbents used in this experiment as shown on Table III Bb fitted better with intraparticle diffusion kinetic than pseudo-second-order kinetic.

TABLE III A: ADSORPTION KINETIC MODEL CONSTANTS FOR THE REMOVAL OF LEAD (PB)

\begin{tabular}{|c|c|c|c|c|c|c|c|}
\hline \multirow[b]{2}{*}{ Adsorbents } & \multirow{2}{*}{$\begin{array}{c}\mathrm{q}_{\mathrm{e}, \exp } \\
(\mathrm{mg} / \mathrm{g})\end{array}$} & \multicolumn{3}{|c|}{ Pseudo-first order } & \multicolumn{3}{|c|}{ Pseudo-second order } \\
\hline & & $\mathrm{K}_{\mathrm{f}}(\mathrm{g} / \mathrm{mg} \cdot \min )$ & $\begin{array}{c}\mathrm{q}_{\mathrm{e}, \mathrm{cal}} \\
(\mathrm{mg} / \mathrm{g})\end{array}$ & $\mathrm{R}^{2}$ & $\mathrm{~K}_{\mathrm{s}}(\mathrm{g} / \mathrm{mg} \cdot \min )$ & $\mathrm{qe}_{\text {,cal }}(\mathrm{mg} / \mathrm{g})$ & $\mathrm{R}^{2}$ \\
\hline CSAC & 0.155925 & 0.186139 & 0.155822 & 0.998776 & 6.311069357 & 0.1578150 & 0.856 \\
\hline PKSAC & 0.155925 & 0.338535 & 0.155766 & 0.818312 & 50.37180073 & 0.1560913 & 0.987 \\
\hline PKCAC & 0.15595 & 0.352876 & 0.155832 & 0.883904 & 68.50599128 & 0.1560493 & 0.972 \\
\hline CAC & 0.15575 & 0.266836 & 0.152454 & 0.543857 & 11.84909063 & 0.1539730 & 0.637 \\
\hline \multirow[b]{2}{*}{ Adsorbents } & \multirow[b]{2}{*}{$\begin{array}{c}\mathrm{q}_{\mathrm{e}, \exp } \\
(\mathrm{mg} / \mathrm{g})\end{array}$} & \multicolumn{3}{|c|}{ Intra-particle Diffusion } & & & \\
\hline & & $\begin{array}{c}\mathrm{K}_{\mathrm{ip}} \\
\left(\mathrm{mg} / \mathrm{g} \cdot \min ^{1 / 2}\right)\end{array}$ & $\mathrm{C}(\mathrm{mg} / \mathrm{g})$ & $\mathrm{q}_{\mathrm{e}, \mathrm{cal}}(\mathrm{mg} / \mathrm{g})$ & & $a^{2}$ & \\
\hline CSAC & 0.155925 & 0.000723 & 0.148534 & 0.154825 & 0.637809 & & \\
\hline PKSAC & 0.155925 & 0.000145 & 0.154501 & 0.155644 & 0.851408 & & \\
\hline PKCAC & 0.15595 & 0.0000941 & 0.154963 & 0.155744 & 0.806983 & & \\
\hline CAC & 0.15575 & 0.00087 & 0.145232 & 0.1521 & 0.816526 & & \\
\hline
\end{tabular}


TABLE III B: ADSORPTION KINETIC MODEL CONSTANTS FOR THE REMOVAL OF CADMIUM (CD)

\begin{tabular}{|c|c|c|c|c|c|c|c|}
\hline \multirow[b]{2}{*}{ Adsorbent } & \multirow{2}{*}{$\begin{array}{c}\mathrm{q}_{\mathrm{e}, \exp } \\
(\mathrm{mg} / \mathrm{g})\end{array}$} & \multicolumn{3}{|c|}{ Pseudo-first order } & \multicolumn{3}{|c|}{ Pseudo-second order } \\
\hline & & $\mathrm{K}_{\mathrm{f}}(\mathrm{g} / \mathrm{mg} \cdot \min )$ & $\mathrm{q}_{\mathrm{e}, \mathrm{cal}}(\mathrm{mg} / \mathrm{g})$ & $\mathrm{R}^{2}$ & $\mathrm{~K}_{\mathrm{s}}(\mathrm{g} / \mathrm{mg} \cdot \mathrm{min})$ & $\begin{array}{c}\mathrm{qe}_{, \mathrm{cal}} \\
(\mathrm{mg} / \mathrm{g})\end{array}$ & $\mathrm{R}^{2}$ \\
\hline CSAC & 0.0907 & 0.187827 & 0.0877993 & 0.56878 & 6.564927 & 0.090056 & 0.716 \\
\hline PKSAC & 0.09075 & 0.2374288 & 0.087562 & 0.53569 & 12.56569 & 0.088988 & 0.619 \\
\hline PKCAC & 0.0908 & 0.2342341 & 0.0880262 & 0.53393 & 11.65175 & 0.089466 & 0.624 \\
\hline $\mathrm{CAC}$ & 0.0906 & 0.2244527 & 0.0874525 & 0.55262 & 11.06641 & 0.089036 & 0.656 \\
\hline \multirow[b]{2}{*}{ Adsorbent } & & \multicolumn{3}{|c|}{ Intra-particle Diffusion } & & & \\
\hline & $\begin{array}{c}\mathrm{q}_{\mathrm{e}, \exp } \\
(\mathrm{mg} / \mathrm{g})\end{array}$ & $\begin{array}{c}\mathrm{K}_{\mathrm{ip}} \\
\left(\mathrm{mg} / \mathrm{g} \cdot \min ^{1 / 2}\right)\end{array}$ & $\mathrm{C}(\mathrm{mg} / \mathrm{g})$ & $\mathrm{q}_{\mathrm{e}, \mathrm{cal}}(\mathrm{mg} / \mathrm{g})$ & & $\mathrm{R}^{2}$ & \\
\hline CSAC & 0.0907 & 0.001105 & 0.077632 & 0.087248 & 0.921587 & & \\
\hline PKSAC & 0.09075 & 0.000816 & 0.080803 & 0.087244 & 0.785414 & & \\
\hline PKCAC & 0.0908 & 0.000802 & 0.081067 & 0.087728 & 0.814781 & & \\
\hline CAC & 0.0906 & 0.000867 & 0.080222 & 0.087064 & 0.834752 & & \\
\hline
\end{tabular}

\section{F. Adsorption Isotherm}

There are several isotherm models available for analyzing experimental adsorption equilibrium parameters, however the Langmuir and Freundlich models are commonly used. Tables IV A and IV B show the model parameters and the statistical fits of the adsorption data to Langmuir and Freundlich models. The coefficient of determination was calculated by fitting the experimental equilibrium data for $\mathrm{Pb}$ and $\mathrm{Cd}$ adsorption onto the different adsorbent performances using the two models. The results on Table IV A shows that, the adsorption of $\mathrm{Pb}$ onto CSAC and PKSAC fits well with the Freundlich model while the adsorption of $\mathrm{Pb}$ onto PKCAC and CAC fit with both Langmuir and Freundlich models. The result on Table IV B for the adsorption of $\mathrm{Cd}$ onto the different adsorbents show that the Freundlich model is a good fit to the experimental adsorption data. The Langmuir isotherm model assumes a finite number of active sites which are homogenously distributed over the surface of the adsorbent [11]. The active sites have the same affinity for adsorption of a mono molecular layer and there is no interaction between the adsorbed molecules [12]. This is physical adsorption due to weak Van der Waal forces.

The Freundlich isotherm model applies to adsorption on heterogeneous surface, and it is a multilayer adsorption [13].

From Tables IV A, the finding of adsorption of $\mathrm{Pb}$ onto PKCAC and CAC fitting well with both Langmuir and Freundlich models corroborates the finding of [10] for the adsorption of heavy metal from aqueous solution onto activated carbon adsorbent.

TABLE IV A: ADSORPTION ISOTHERM CONSTANT FOR THE REMOVAL OF LEAD (PB)

\begin{tabular}{ccccccc}
\multicolumn{3}{c}{ TABLE IV A: ADSORPTION ISOTHERM CONSTANT FOR THE REMOVAL OF LEAD (PB) } \\
\cline { 2 - 7 } Adsorbent & \multicolumn{3}{c}{ Langmuir } & \multicolumn{3}{c}{ Freundlich } \\
& $\mathrm{q}_{\mathrm{m}}(\mathrm{mg} / \mathrm{g})$ & $\begin{array}{c}\mathrm{K}_{\mathrm{L}} \\
(\mathrm{L} / \mathrm{mg})\end{array}$ & $\mathrm{R}^{2}$ & $\mathrm{~K}_{\mathrm{f}}(\mathrm{mg} / \mathrm{g})$ & $\mathrm{N}$ & $\mathrm{R}^{2}$ \\
\hline CSAC & 1.259172 & 12.122 & 0.837 & 1.095641 & 1.44044 & 0.955736 \\
PKSAC & 0.676528 & 38.219 & 0.869 & 0.824011 & 3.52309 & 0.948091 \\
PKCAC & 23.48114 & 0.4099 & 0.986 & 9.053736 & 1.01271 & 0.987868 \\
CAC & 2.248968 & 1.0127 & 0.952 & 1.31664 & 1.22748 & 0.950246 \\
\hline
\end{tabular}

\begin{tabular}{ccccccc} 
TABLE IV B: ADSORPTION KINETIC MODEL CONSTANTS FOR THE REMOVAL OF CADMIUM (CD) \\
\cline { 2 - 7 } Adsorb & \multicolumn{5}{c}{ Langmuir } \\
\cline { 2 - 7 } ent & $\mathrm{q}_{\mathrm{m}}(\mathrm{mg} / \mathrm{g})$ & $\begin{array}{c}\mathrm{K}_{\mathrm{L}} \\
(\mathrm{L} / \mathrm{mg})\end{array}$ & $\mathrm{R}^{2}$ & $\begin{array}{c}\mathrm{K}_{\mathrm{f}} \\
(\mathrm{mg} / \mathrm{g})\end{array}$ & $\mathrm{N}$ & $\mathrm{R}^{2}$ \\
\hline CSAC & 0.322467 & 187.86 & 0.525 & 4.8007 & 1.2534 & 0.79295 \\
PKSAC & 135.8941 & 0.0298 & 0.517 & 1.9712 & 0.0351 & 0.924581 \\
PKCAC & 305.4831 & 0.0134 & 0.630 & 6.0403 & 0.05797 & 0.864445 \\
CAC & 348.9372 & 0.0138 & 0.513 & 1.3242 & 6 & 0.945523 \\
\hline
\end{tabular}

\section{G. Statistical Analysis of Adsorption Properties of the Bio- adsorbents}

The result of the statistical analysis of differences in adsorption performance of the different bio-adsorbents using Kruskal Wallis are presented on Tables $\mathrm{V}$ and $\mathrm{VI}$ for $\mathrm{Pb}$ and $\mathrm{Cd}$, respectively. Kruskal Wallis test is a non-parametric procedure that can be used to compare more than two populations. It identifies by ranks if three or more independent samples were selected from populations having the same distribution.

\section{1) Lead ( $\mathrm{Pb})$ Adsorption}

Result in Table $\mathrm{V}$ a reveals that there is no significant difference in the amount of $\mathrm{Pb}$ adsorbed for the different types of adsorbents used $(\mathrm{P}>0.05)$, contact time $(\mathrm{P}>0.05)$ while initial adsorbate concentration $(\mathrm{P}<0.05)$ and adsorbent mass
$(\mathrm{P}<0.01)$ gave significant results with optimal $\mathrm{Pb}$ adsorption occurring at initial concentration of $15.62 \mathrm{mg} / \mathrm{l}$ and adsorbent mass of $1 \mathrm{~g}$. The percentage of $\mathrm{Pb}$ removed differ significantly between the three types of adsorbents $(\mathrm{P}<0.01)$ at the initial concentration $(\mathrm{P}<0.01)$ and contact time $(\mathrm{P}<0.01)$ while adsorbent mass gave insignificant result $(\mathrm{P}>0.05)$. Result indicates that the highest percentage $\mathrm{Pb}$ removal was achieved when PKCAC was used (in preference to the other adsorbents) while in terms of initial concentration and contact time, the optimal result was obtained at $3.12 \mathrm{mg} / \mathrm{l}$ initial concentration and 135 minutes contact time.

\section{2) Cadmium (Cd) Adsorption}

Result in Table VI shows no significant difference in the amount of $\mathrm{Cd}$ adsorbed when the different types of the adsorbents were used $(\mathrm{P}=0.985)$ and contact time $(\mathrm{P}>0.05)$ 
while significant results were obtained at the initial adsorbate concentration $(\mathrm{P}<0.01)$ and adsorbent mass $(\mathrm{P}<0.01)$ with initial concentration of $9.09 \mathrm{mg} / \mathrm{l}$ and adsorbent mass of $1 \mathrm{~g}$ giving the highest amount of $\mathrm{Cd}$ adsorbed. There was no significant difference in $\%$ of $\mathrm{Cd}$ removed due to the different types of adsorbents $(\mathrm{P}>0.05)$ and adsorbent mass $(\mathrm{P}>0.05)$ whereas significant difference in $\%$ of $\mathrm{Cd}$ removed were obtained in relation to initial adsorbate concentration $(\mathrm{P}<0.05)$ and contact time $(\mathrm{P}<0.01)$. Result reveals that initial concentration of $9.09 \mathrm{mg} / \mathrm{l}$ and contact time of 135.00 minutes gave the highest $\%$ of $\mathrm{Cd}$ removed.

TABLE V: KRUSKal WALlis Result of DifFERENCES IN THE AMOUNT OF PB AdSORBED AND ADSORPTION EFFICIENCY BASED ON ADSORBENT TYPE, INITIAL CONCENTRATION, ADSORBENT MASS AND CONTACT TIME

\begin{tabular}{|c|c|c|c|c|c|c|}
\hline \multirow[b]{2}{*}{$\begin{array}{c}\text { Types of } \\
\text { adsorbent }\end{array}$} & \multicolumn{3}{|c|}{ Amount of $\mathrm{Pb}$ adsorbed } & \multicolumn{3}{|c|}{$\%$ of $\mathrm{Pb}$ removed } \\
\hline & $\begin{array}{c}\text { Mean } \\
\text { rank }\end{array}$ & $\begin{array}{c}\text { Kruskal- } \\
\text { Wallis } \\
\chi^{2}\end{array}$ & P-value & $\begin{array}{c}\text { Mean } \\
\text { rank }\end{array}$ & $\begin{array}{c}\text { Kruskal- } \\
\text { Wallis } \\
\chi^{2}\end{array}$ & P-value \\
\hline CSAC & 39.95 & & & 45.40 & & \\
\hline PKSAC & 39.47 & 2.615 & 0.455 & 39.36 & 18.729 & $0.000 * *$ \\
\hline PKCAC & 41.32 & 2.015 & 0.453 & 46.68 & 10.129 & 0.000 \\
\hline CAC & 30.86 & & & 19.25 & & \\
\hline Initial conc & & & & & & \\
\hline 3.12 & 30.00 & & & 42.61 & & \\
\hline 6.25 & 61.50 & & & 29.25 & & \\
\hline 9.37 & 65.50 & 37.957 & $0.0000 * *$ & 23.75 & 13.541 & $0.009 * *$ \\
\hline 12.50 & 69.50 & & & 16.25 & & \\
\hline 15.62 & 73.50 & & & 14.75 & & \\
\hline $\begin{array}{c}\text { Adsorbent } \\
\text { mass }\end{array}$ & & & & & & \\
\hline 1 & 46.00 & & & 37.53 & & \\
\hline 1.5 & 10.67 & & & 42.08 & & \\
\hline 2.0 & 10.50 & 37.588 & $0.0000 * *$ & 38.50 & 0.521 & 0.971 \\
\hline 2.50 & 6.50 & & & 41.50 & & \\
\hline 3.0 & 2.00 & & & 31.50 & & \\
\hline $\begin{array}{l}\text { Contact } \\
\text { time }\end{array}$ & & & & & & \\
\hline 15.00 & 22.88 & & & 14.38 & & \\
\hline 30.00 & 30.25 & & & 35.00 & & \\
\hline 45.00 & 33.00 & & & 38.00 & & \\
\hline 60.00 & 36.24 & & & 31.40 & & \\
\hline 75.00 & 40.50 & 8235 & 0511 & 47.50 & 29398 & $00010 * *$ \\
\hline 90.00 & 42.75 & 0.253 & 0.011 & 50.50 & 29.070 & 0.0010 \\
\hline 105.00 & 50.00 & & & 63.13 & & \\
\hline 120.00 & 52.13 & & & 65.63 & & \\
\hline 135.00 & 57.00 & & & 71.25 & & \\
\hline 150.00 & 55.50 & & & 69.50 & & \\
\hline
\end{tabular}

* Significant at $5 \%(\mathrm{p}<0.05),{ }^{*}$ significant at $1 \%(\mathrm{p}<0.01)$.

\section{H. Adsorption Capacity Model}

Three parameters were used to develop a mathematical model that relate Adsorption Capacity (AC) to contact time (t), adsorbate concentration $(\mathrm{Co})$ and adsorbent mass $(\mathrm{M})$ for the adsorption of $\mathrm{Pb}$ and $\mathrm{Cd}$ onto the different adsorbents (Equation (4)). The developed adsorption coefficients and exponential constants for the different adsorbents are summarized on Tables VII and VIII for $\mathrm{Pb}$ and $\mathrm{Cd}$, respectively.

$$
A C=\alpha_{0}\left(\frac{t^{\alpha_{1}} \times C^{\alpha_{2}}}{M^{\alpha_{3}}}\right)
$$

TABLE VI: KRUSKAL WALLIS RESULT OF DIFFERENCES IN THE AMOUNT OF CD ADSORBED AND ADSORPTION EFFICIENCY BASED ON TYPE, INITIAL

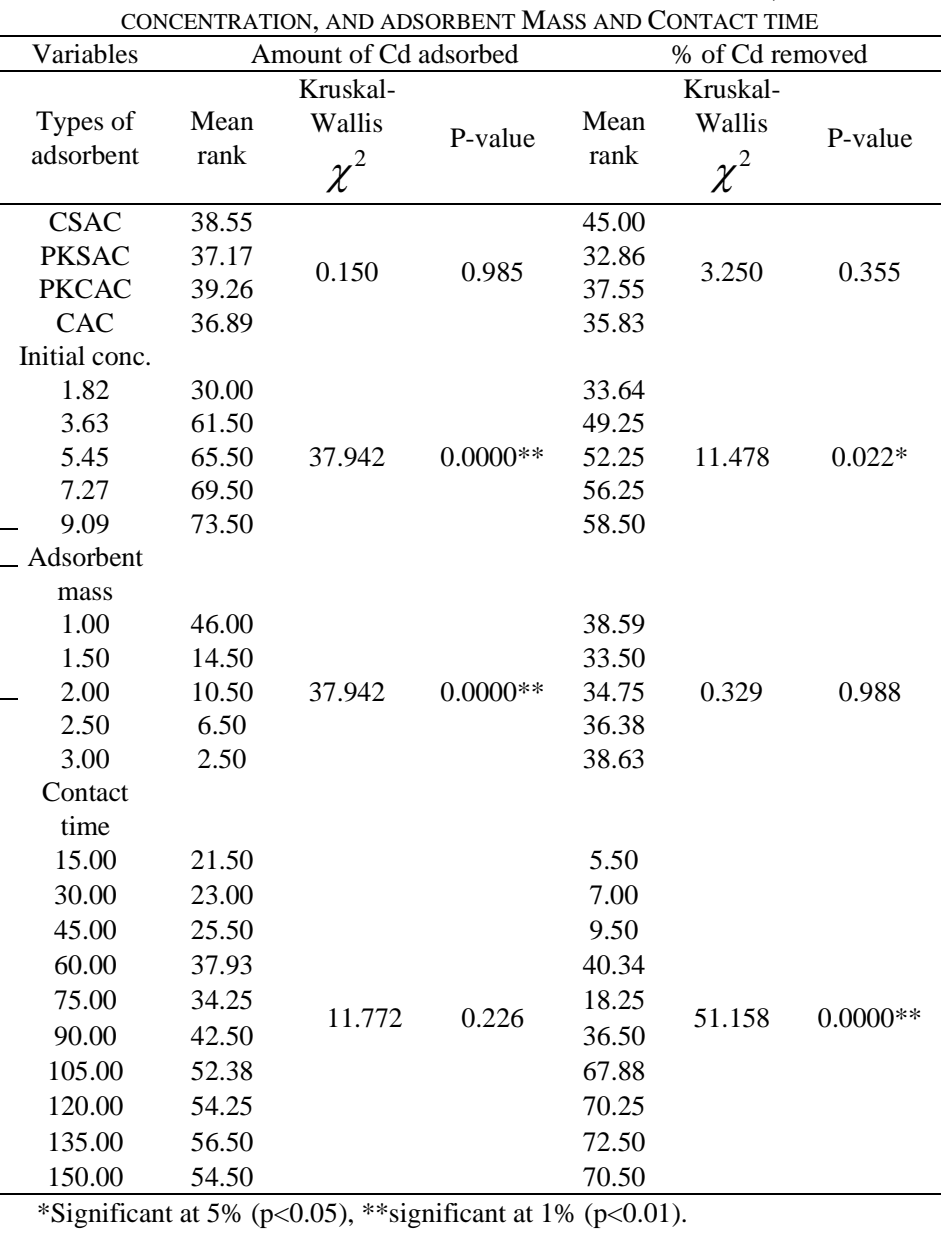

Result shown in Table VII reveals that for all the adsorbent considered, more than $99.0 \%$ of the variation in adsorption capacity was accounted for by initial concentration, contact time and adsorbent mass. The adsorption of $\mathrm{Pb}$ onto the different adsorbents (CAC, CSAC and PKCAC), had $(\mathrm{P}<0.05)$ which means that, as contact time and initial concentration increase significantly, there is a corresponding significant increase in adsorption of $\mathrm{Pb}$ while as the absorbent mass increases significantly, the adsorption capacity decreases significantly except for PKSAC where $\mathrm{P}>0.05$ for contact time. This relationship between adsorption capacity and contact time, initial concentration and adsorbent mass is supported by [12], [1]. Results presented in Table VIII reveal that in all the adsorbents considered, more than $99.0 \%$ of the variation in adsorption capacity of the adsorbents for $\mathrm{Cd}$ adsorption was accounted for by initial concentration, contact time and adsorbent mass. The results show that; contact time, initial concentration and adsorbent mass all have significant impact on the adsorption capacity of CAC, CSAC, PKCAC and $\mathrm{PKSAC}$ for $\mathrm{Pb}$ adsorption $(\mathrm{P}<0.05)$. This result implies that as the contact time and initial concentration increase significantly, there is a corresponding significant increase in adsorption capacity for $\mathrm{Cd}$ while as the adsorbent mass increases significantly, the adsorption capacity decreases significant $(\mathrm{P}<0.05)$ for the four types of adsorbents. 
TABLE VII: SUMMARY OF THE ESTIMATES OF THE AC MODELS FOR PB FOR THE DIFFERENT TYPES OF ABSORBENT

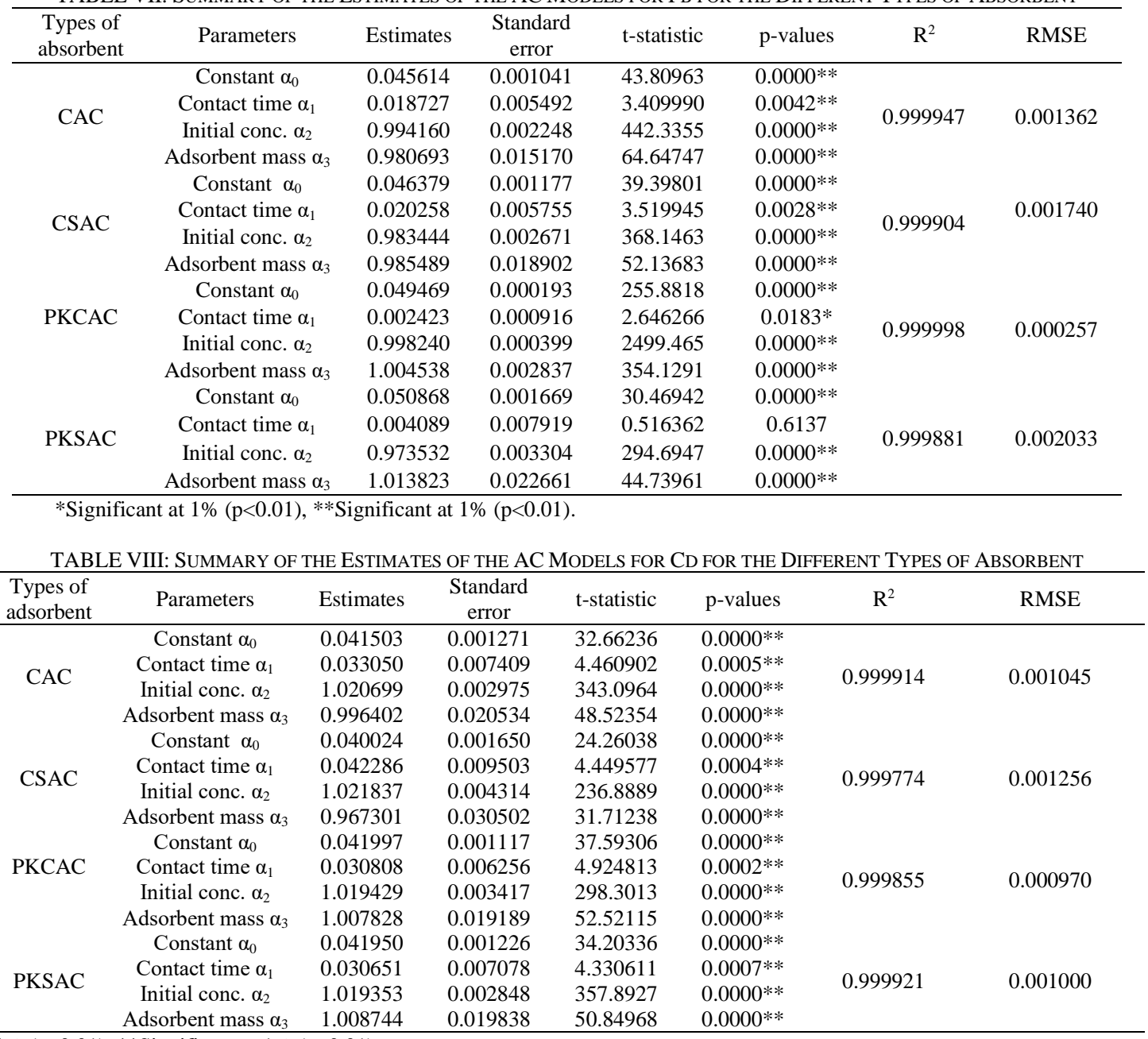

* Significant at $1 \%(\mathrm{p}<0.01),{ }^{*}$ Significant at $1 \%(\mathrm{p}<0.01)$.

\section{CONCLUSION}

This study was undertaken to evaluate the adsorption of Lead and Cadmium on activated carbons from commonly available agricultural wastes. The prepared carbon from the byproducts of coconut and palm kernel competed effectively with commercial activated Carbon for the adsorption of the metals and can be used for domestic water treatment. The adsorption of $\mathrm{Pb}$ and $\mathrm{Cd}$ on the activated carbons was found to be dependent on time, initial concentration of adsorbate and dose of adsorbent.

The removal efficiency of the different adsorbents was above $93 \%$ within 60 minutes for both metal ions. The kinetic data follow pseudo first order kinetic model for adsorption of $\mathrm{Pb}$ on CSAC, while pseudo second order for PKSAC and PKCAC. The intra-particle diffusion was the rate limiting step for $\mathrm{Pb}$ adsorption onto the commercial carbon. Cadmium adsorption on all the activated carbons used, followed the intraparticle diffusion kinetic.

The adsorption behavior of $\mathrm{Pb}$ and $\mathrm{Cd}$ was described by Langmuir and Freundlich isotherms, but the equilibrium data fitted best into the Freundlich equation for the adsorption of $\mathrm{Cd}$ on to all the activated carbons but the adsorption of $\mathrm{Pb}$ on CSAC and PKSAC fitted best into Freundlich isotherm, while adsorption onto PKCAC and CAC fitted both Langmuir and Freundlich isotherms well. There was no statistically significant difference in the amount of adsorbate adsorbed on to the activated carbons based on the types of adsorbents, however, the removal efficiency was different for $\mathrm{Pb}$ adsorption.

This study showed that the prepared activated carbons from the locally available low-cost bio-wastes can effectively remove $\mathrm{Pb}$ and $\mathrm{Cd}$ from aqueous solution to avert expensive commercial adsorbents.

\section{REFERENCES}

[1] N. U. Udeh and J. C. Agunwamba,"Removal of Heavy Metals from Aqueous Solution using Bamboo Based Activated Carbon". International journal of Engineering Inventions, vol.6(2): 01-12, 2017.

[2] M. MadhavaRao, A. Ramesh, R, G. PurnaChandra and K. Seshaiah, "Removal of Copper and Cadmium from the Aqueous Solutions by Activated Carbon derived from Ceibapentandra Hulls". Journal of Hazardous Materials, 123-129. doi: 10.1016/j.jhazmat.2005.08.018, 2005.

[3] S. Sumathi, S. Bhatia, K. T. Lee and A. R. Mohamed, "Optimization of microporous palm shell activated carbon production for flue gas desulphurization: Experimental and statistical studies," Bioresource Technology 100, p. 1614, 2009.

[4] M.A. Alkhatib, S. Muyibi and J. Amode, "Optimization of activated carbon production from empty fruit bunch fibers in one-step steam pyrolysis for cadmium removal from aqueous solution," The Environmentalist 31, p. 349, 2011.

[5] S. E. Abechi, C. E. Gimba, A. Uzairu, and Y. A. Dallatu, "Preparation and Characterization of Activated Carbon from Palm Kernel Shell by Chemical Activation," Research Journal of Chemical Sciences, 3(7): 5461, 2013.

[6] P. C. N. Ejikeme, M. Ejikeme and G. N. Okonkwo, "Equilibrium, Kinetic and Thermodynamic Studies on Basic Dye Adsorption using Composite Activated Carbon," International Journal of Technical research and Application, 2, 96-103, 2014. 
[7] C. L. Lee, P. S. H'ng, M. T. Paridah, K. L. Chin, U. Rashid, M. Maminski and P. S. Khoo, "Production of Bioadsorbent from Phosphoric Acid Pretreated Palm Kernel Shell and Coconut Shell by Two-Stage Continuous Physical Activation via $\mathrm{N}_{2}$ and Air," Royal Society Open Science, 5: 180775.doi.org/10.1098/rsos.180775, 2018.

[8] K. C. Jun, A. A. AbdulRaman and A. Buthiyappan, "Treatment of Oil Refinery Effluent using Bio-Adsorbent Developed from Activated Palm Kernel Shell Zeolite," Royal Society of Chemistry Advances.doi: $10.1039 / \mathrm{d} 0 \mathrm{ra} 03307 \mathrm{c}, 2020$.

[9] A. Allwar, "Preparation and Characteristics of Activated Carbon from Oil Palm Shell for Removal of Iron and Copper from Patchouli Oil," International Journal of Applied Chemistry, 12(3): 183-192, 2016.

[10] M. Ullah, R. Nazir, W. Khan, M. Shah, S. G. Afridi and A. Zada, "The Effective Removal of Heavy Metals from Water by Activated Carbon Adsorbents of Albizialebbeck and Meliaazedarach Seed Shells," Soil and Water Research, 15: 30-37.doi.org/10.17221/212/2018-swr, 2020.

[11] I. Langmuir, "The Constitution and Fundamental Properties of Solid and Liquids," Journal of American Chemistry Society, 39: 2221- 2295, 1916

[12] G. Vijayakumar, R. Tamilarasan and M. Dharmendirakumar, "Adsorption, Kinetic, Equilibrium and Thermothynamic Studies on the Removal of Basic Dye Rhodamine-B from Aqueous Solution by the use of Natural Adsorbent Perlite," J. Mater. Environ. Sci., 3(1): 157-170, 2012.

[13] H. M. F. Feundlich, "Over the Adsorption in the Solution". Journal of Physical Chemistry 57A: 385- 470, 1906. 